\title{
A Systematic Literature Review on Antecedents of Consumer Engagement
}

\author{
KHURRAM SHAHZAD KHAN \\ Department of Marketing, Faculty of Management Sciences, \\ International Islamic University, Islamabad, Pakistan. \\ Email: Khurramniazi555@gmail.com \\ Tel: +923157500210 \\ Dr. ABDUL ZAHID KHAN \\ Assistant Professor, Department of Technology Management, Faculty of Management Sciences, \\ International Islamic University, Islamabad, Pakistan, \\ Email: Zahidkhan.fms@iiu.edu.pk \\ Tel: +923335285550 \\ Prof. Dr. MOHAMMAD BASHIR KHAN \\ Department of Marketing, Faculty of Management Sciences, \\ International Islamic University, Islamabad, Pakistan. \\ Email: Drmohdbashir@live.com \\ Tel: +923009090919
}

\begin{abstract}
The major dilemma of marketing professionals is to justify the investment or expenditure on activities related to consumer engagement. Antecedents of consumer engagement are deeply rooted in the unique and specific differences that countries and/or regions present in terms of their social, legal, economic, political, and technological dimensions. Antecedents must be different for consumers from country a, region 1 than country b, region 2. There cannot be a commonality of antecedents for the 196 countries in the world. This research is among the first steps to make it possible. First, this research performed rigorous systematic literature review to consolidate all antecedents of consumer engagement acknowledged in previous quality research papers. Second, a systematic endeavour to generalize the antecedents of consumer engagement that fits all situation and context. The third contribution is the future research agenda of consumer engagement that is yet to be explored. For this purpose, strict inclusion and exclusion criteria implemented. Among hundreds of articles, a total 42 articles were selected, which fulfilled the criteria. Strict criteria were necessary to improve the quality of work. The study compiled all the antecedents in a table and concluded some highly ranked and high-frequency antecedents. A total of 22 antecedents were concluded among which, the study has discussed the topmost highly relevant yet most essential antecedents of consumer engagement. This study generalized the antecedents under broader terms. These top antecedents which are most essential are social, value, identity, interaction, involvement, experience, satisfaction, information, attachment, and participation. In the analysis part, all top antecedents discussed along with future research directions.
\end{abstract}

Keywords: Consumer Engagement, Customer Engagement, Systematic Literature Review, SLR.

\section{Introduction}

The major dilemma of marketing professionals is to justify the investment or expenditure on activities related to consumer engagement (Bilro \& Loureiro, 2020) as engagement is one of the most prioritized area 
of research since 2010. The word 'engagement' has a 500-year-old history (Axelson \& Flick, 2010), but in the marketing, engagement concept introduced less than a decade ago. Interestingly, there is no such agreed definition of engagement concept. Different authors have defined engagement differently depending upon the focal object and context. Engagement concept is so versatile that even after a decade of research, there is no consensus upon its unidirectionality or multidimensionality (Unal, Schivinski, \& Brzozowska-Woś, 2017). Researchers have different opinions regarding its dimensions. Diverse definitions, dimensions, and context have created confusion in the conceptualization of consumer engagement and its dimensions (Dessart, Veloutsou, \& Morgan-Thomas, 2016; Kunz et al., 2017).

It is of great concern that despite the acknowledged importance of consumer engagement, fragmented research with various conceptualization, definition and lack of alignment may result into misinterpretation and divergence in future research (Bilro \& Loureiro, 2020). To manage the antecedents or consequence of consumer engagement, one must pay attention to the definition of consumer engagement in the very prospective or context.

The concept of customer engagement has been researched and defined in different perspectives. According to Kunz et al. (2017), these perspectives may be; psychological processes, motivational psychology, and behavioral manifestation. Although, Unal et al. (2017) broadly separate the authors' work on engagement in Marketing discipline so far in two areas; Some authors claim engagement as a psychological state while another claim that engagement is a behavioral state. Many authors have propagated the notion that engagement is a psychological state (e.g., (Abdul-Ghani, Hyde, \& Marshall, 2018; Bowden, 2009; Brodie, Hollebeek, Jurić, \& Ilić, 2011; Calder, Malthouse, \& Schaedel, 2009; Higgins \& Scholer, 2009; Hollebeek, 2011; Hollebeek, Srivastava, \& Chen, 2019; Patterson, Yu, \& De Ruyter, 2006).

According to Bowden (2009), customer engagement is a psychological process that encapsulated the mechanism which forms loyalty for new customers and ensures loyalty retention for repeat customers of a service brand. Some studies conceptualize consumer engagement as a psychological state that ascends in services relationships due to collaborative and mutually creative experiences with brand (Brodie et al., 2011; Brodie, Ilic, Juric, \& Hollebeek, 2013).

On the other hand, the idea that engagement is a behavioral state claimed by many researchers (Jaakkola \& Alexander, 2014; V. Kumar et al., 2010; Schivinski, Christodoulides, \& Dabrowski, 2016; Van Doorn et al., 2010; Verhoef, Reinartz, \& Krafft, 2010). Van Doorn et al. (2010) researched customer engagement in the context of the behavioral state of customers and stated that engagement is a behavioral manifestation that goes beyond transaction and can precisely be described as a behavioral manifestation of customers focused on a brand of the firm, beyond purchase and emerges from motivational drivers. Verhoef et al. (2010) also identified customer engagement as behavioral manifestation towards a firm or brand that goes beyond transactions. Different perspectives, definitions, context, and situations steer the antecedents of engagement for a consumer.

\section{Why Systematic Literature Review on Antecedents of Consumer Engagement Is Needed:}

Antecedents of consumer engagement are deeply rooted in the unique and specific differences that countries and/or regions present in terms of their social, legal, economic, political, and technological dimensions. Antecedents must be different for consumers from country a, region 1 than country b, region 2 . There cannot be a commonality of antecedents and consequences for the 196 countries in the world. This research is among the first steps to make it possible.

Since the boom of consumer/customer engagement concepts, researchers have addressed different aspects of antecedents of customer/consumer engagement. There is a lack of consensus on the specific antecedents of consumer engagement in the literature of business practices, the management, or social science (Brodie et al., 2011). Based on the definitions and the specific angle from which the researchers perceived, the 
engagement had affected the variables included in different models for antecedents and consequences. Although, these intermingled concepts have confused the antecedents of consumer engagement but made it exciting and beneficial at the same time. Different cultures, different industries, and different methods have confused it, but they have enhanced its depth too. Moreover, it is imperative to comprehend the antecedents of customer engagement to aid firms to refine their strategic approaches by concentrating on the comprehensive process of engaging consumers (Pansari \& Kumar, 2017).

The first contribution of this research is the rigorous systematic literature review to consolidate all antecedents of consumer engagement acknowledged in previous quality research papers. These antecedents belong to various context, regions, or situations. There are few published literature reviews on consumer engagement but they are more inclined towards the consumer engagement construct as a whole while this research is first to thoroughly and specifically address the antecedents of consumer engagement (Bilro \& Loureiro, 2020; Unal et al., 2017). Second contribution of the research paper is the endeavor to generalize the antecedents of consumer engagement that fits all situation and context. The third contribution is the future research agenda of consumer engagement that is yet to be explored.

After the introduction, the research paper is further organized into five sections. Section two has addressed the methodology part. Section 3 covers the finding, while section 4 has covered the analysis and discussion part. In section five, the conclusion, implication, and future research directions have been given.

\section{Methodology}

A systematic and reproducible process of identifying, evaluating, and synthesizing the existing body of knowledge is called a literature review (Fink, 2019). Levy \& Ellis (2006) explained the literature review as a step-by-step process to accumulate, know, understand, apply, evaluate, and synthesize the literature to stipulate a strong underpinning of a topic.

According to Kitchenham \& Charters (2007), a useful literature review must have the following features:

(i) Must have defined a review protocol so that a research question can be specified.

(ii) It must have defined search strategies.

(iii) Search strategies must be documented to access reproducibility, rigor, and completeness.

(iv) Must have unambiguous inclusion and exclusion criteria of a study.

(v) Must have a quality criterion of the studies included in the systematic literature review.

This study practiced the systematic literature review process explained by Kitchenham \& Charters (2007) and Levy \& Ellis (2006). Based on the guidelines provided by the authors, this study is based on a specific research question.

\section{Rationale of the Study}

This rationale of the study is to pinpoint the antecedents of consumer engagement due to which businesses gain a profitable edge and loyal customers with repurchase intent. Moreover, to find out if there are any repeating and generalizable antecedents of consumer engagement. Finally, to explore the future research direction in the context of consumer engagement.

\section{Research Objectives}

This objective of the study is to identify the antecedents of consumer engagement owing to which companies achieve the goals of loyal customers and a profitable edge over competitors. Following are the objectives of the current research. 
(i) To identify the antecedents of consumer engagement identified in the past research.

(ii) To explore the generalizable antecedents of consumer engagement.

(iii) To explore the future research directions in the context of consumer engagement.

\section{A systematic literature review has been incorporated to answer the above research questions.}

\section{Identifying and Selecting Primary Studies:}

For any systematic literature review, the decision to select the data sources is a significant yet challenging task. In this research, the following data sources have been included.

- Web of Science

- Sage Pub

- Taylor \& Francis

- Springer

- Elsevier

- Emerald

- Google Scholar

\section{Literature Search Strings}

Different basic search strings used to retrieve the related literature from different databases, after searching all the databases mentioned above, limited studies were there that addresses the specific keyword. So, different synonyms of "antecedents" were also used to get the maximum related results. for this purpose, following search strings were used; consumer engagement, customer engagement, consumer engagement antecedent, customer engagement antecedent, consumer engagement motives, customer engagement motives, consumer engagement stimulus, customer engagement stimulus, customer engagement driver, consumer engagement driver, customer engagement determinant, consumer engagement determinant, customer engagement motivation, and consumer engagement motivation.

To overcome the irrelevant data issue, advance search options and Boolean operators (or, and, not etc.) and the use of "intitle" etc. were used to retrieve the meaningful and relevant data on the specific keywords.

\section{Inclusion and Exclusion Criteria}

The essence of inclusion criteria is that only relevant and specific studies can be included from the junk of data. For this purpose, special inclusion criteria fashioned to filter the gathered data. The inclusion criteria are as follows.

- Only English language articles were included.

- Article title must clearly state the research aim and relevance to the research question.

- Only full and downloadable research papers were included.

- $\quad$ Published since 1997 to 2019.

- Only those articles having a "Customer/consumer engagement" keyword in the title were included for further review.

- Only articles published in impact factor journals were included.

- Only that thesis, having a decent number of citations were included.

- Highly relevant books chapter from a reputable publishing source were included.

- Highly relevant conference papers having decent citations and reputable sources were included. 
To improve and ensure the quality of research, specific exclusion criteria implemented. Papers excluded based on the following exclusion criteria:

- All non-English papers.

- All duplicate Papers.

- All papers published in other than Impact factor journals.

- All thesis has less than five citations.

- All conference papers that were nonrelated, having fewer citations and not from a reputed source.

- All articles, whose abstract revealed irrelevancy to the research topic.

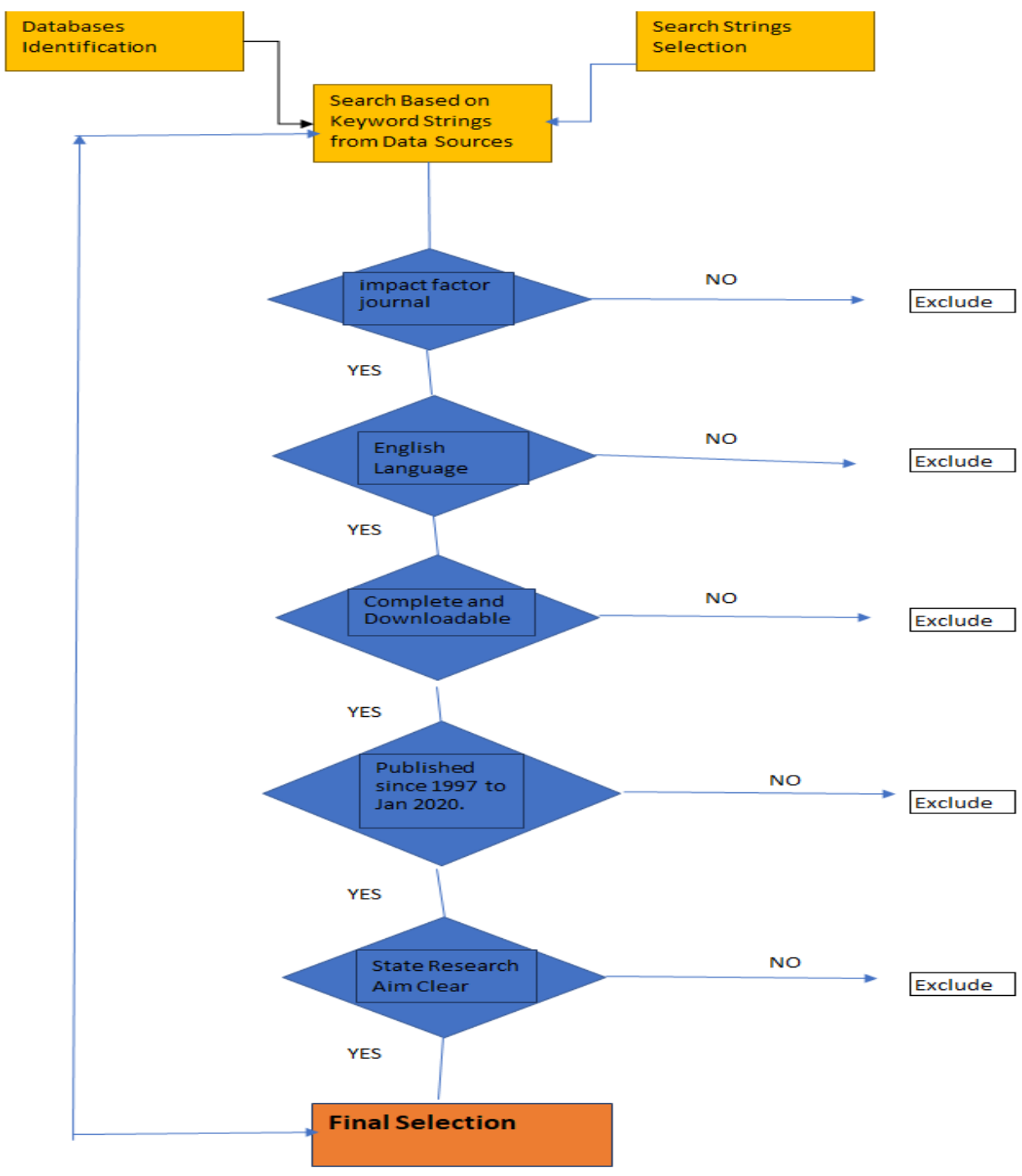

FLOW DIAGRAM BASES ON INCLUSION AND EXCLUSION CRITERION

\section{Conducting the Review}

Initially, reputed sources were researched, based on the specific keyword strings. All this endeavor resulted in some highly relevant research papers but a lot of irrelevant papers too. After that, to improve the 
research specification for research databases, advance search features were used by incorporating, "and" or "in title" options. It improved the output quality a lot.

There was still a chance that some quality research might skip due to technical or human issues. We used the Google Scholar advance research option. We input Consumer Engagement" and "Customer engagement" in the "only in title" option of Google Scholar and recorded all the answers.

To tackle human error, we then brought together all the articles in one excel file, used the duplicate finder option of MS Excel, and omit all the duplicate articles. We cross-check if the articles we extracted from different reputed databases are there in the extracted data from Google Scholar. We find out that all the articles, extracted from resources, other than Google Scholar, were there.

All this endeavor resulted in a total of 1897 article specific to consumer/customer engagement. We reviewed the title of each article and shortlisted the research paper, which was totally relevant to our research. Moreover, further filtering based on the inclusion and exclusion criteria, a total of 106 studies were initially shortlisted for further evaluation.

After further strict evaluation of abstracts of articles and including those studies only from impact factor journals, only 42 studies were finally selected.

Table 1

Database Details

\begin{tabular}{|c|c|}
\hline Database & Article Included \\
\hline Sage Publication & 2 \\
\hline Taylor \& Francis & 10 \\
\hline Springer & 2 \\
\hline Elsevier & 3 \\
\hline Emerald & 6 \\
\hline Thesis & 3 \\
\hline Conference Paper & 3 \\
\hline Book & 3 \\
\hline Google Scholar & 10 \\
\hline Total & 42 \\
\hline
\end{tabular}

Although a total of 106 research papers were shortlisted, only 42 studies were able to meet the inclusion and exclusion criteria. This thorough scrutiny was necessary for the quality of research and one of the basic requirements of any useful systematic literature review.

\section{Findings}

A thorough analysis of the articles revealed exciting results. Consumer engagement is a systematic process, and its antecedents are challenging to generalize due to various rich contexts and settings. Although, after this research, we are now able to generalize some antecedents, which are mostly being repeated in the research on antecedents of consumer engagement.

There are more than a hundred antecedents, we have found from analysis of all the included papers in this research. All the antecedents compiled based on the study, along with the author's name. This compilation of antecedents of consumer engagement revealed that there is much diversity in the understanding of antecedents of consumer engagement. However, there is no doubt about the richness of variables that can contribute to an antecedent of consumer engagement. 
The compilation of antecedents in all studies was a hectic task, yet it resulted in deep insight on the topic. Table 1 shows the compiled data of all the antecedents discussed in the selected research papers. Data revealed that along with general context, antecedents of consumer engagement are also spread across many contexts like brand engagement, social media engagement, especially Facebook, online communities' engagement, etc.

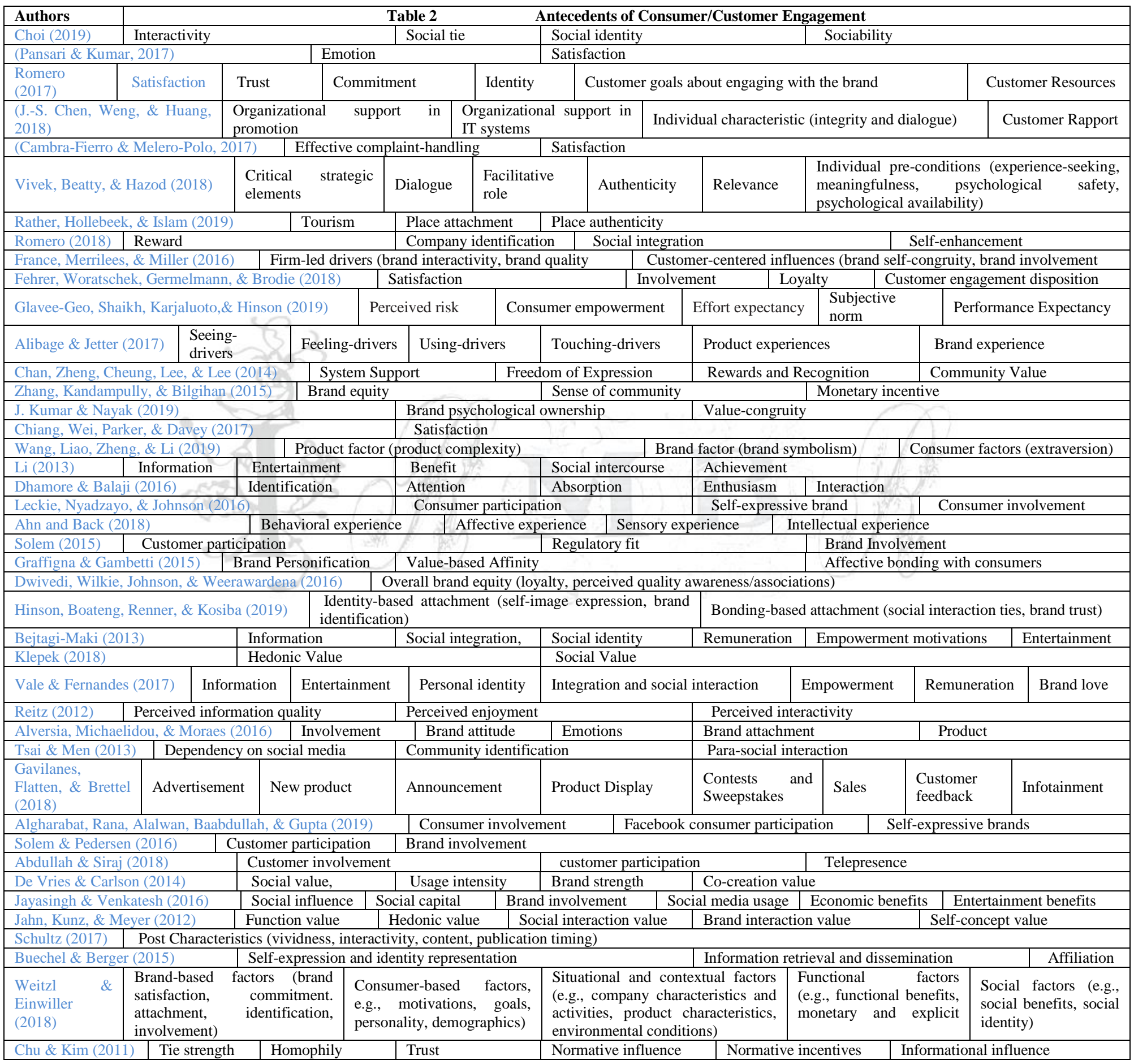


We found that there are some antecedents, which are not bound of the context or particular setting and consistent in most of the cases. We separated those antecedents in Table 2 along with their frequency of reputation. Moreover, we have also discussed the antecedents of consumer engagement based on the particular context and setting. It reveals how a change in context does effect change in the antecedents of consumer engagement.

The current study has arranged all the antecedents in such manner by evaluating if a specific antecedent came under broad antecedent. After the evaluation of the tabulated data, the undermentioned antecedents were separated hierarchically based on the occurrence or frequency.

Table 3: Antecedents of Consumer Engagement Based on Frequency

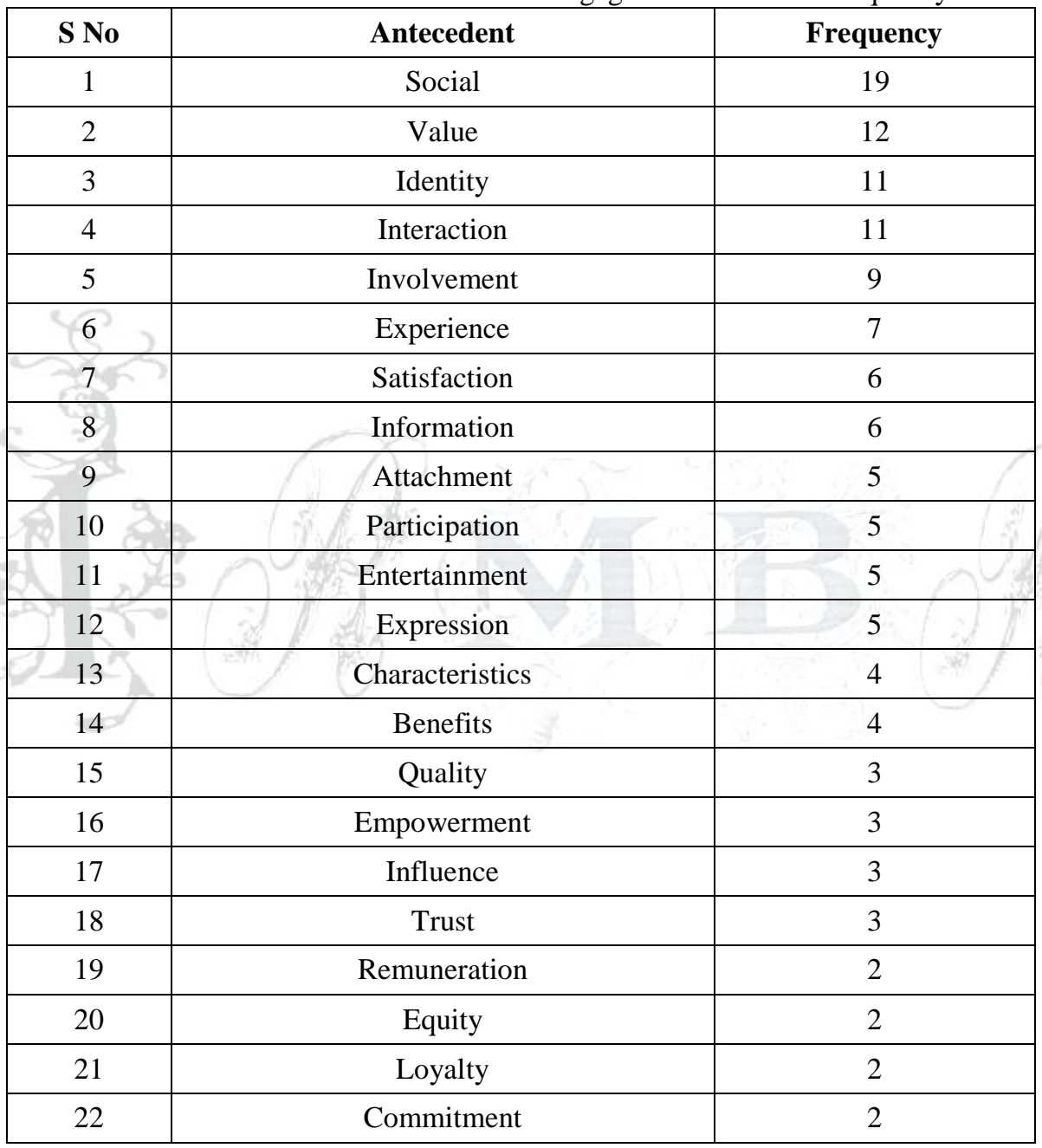

Table 2 revealed that there are some antecedents which are of high importance and have been given due consideration in many pieces of research. For Example, the social antecedent of consumer engagement has established itself as the most researched antecedent. Same as value antecedent is the second most researched antecedent of engagement. identity, interaction, involvement, experience, satisfaction, information, entertainment, and product antecedents are the topmost researched antecedents of consumer engagement. The top ten antecedents will be discussed in the analysis and discussion part. 

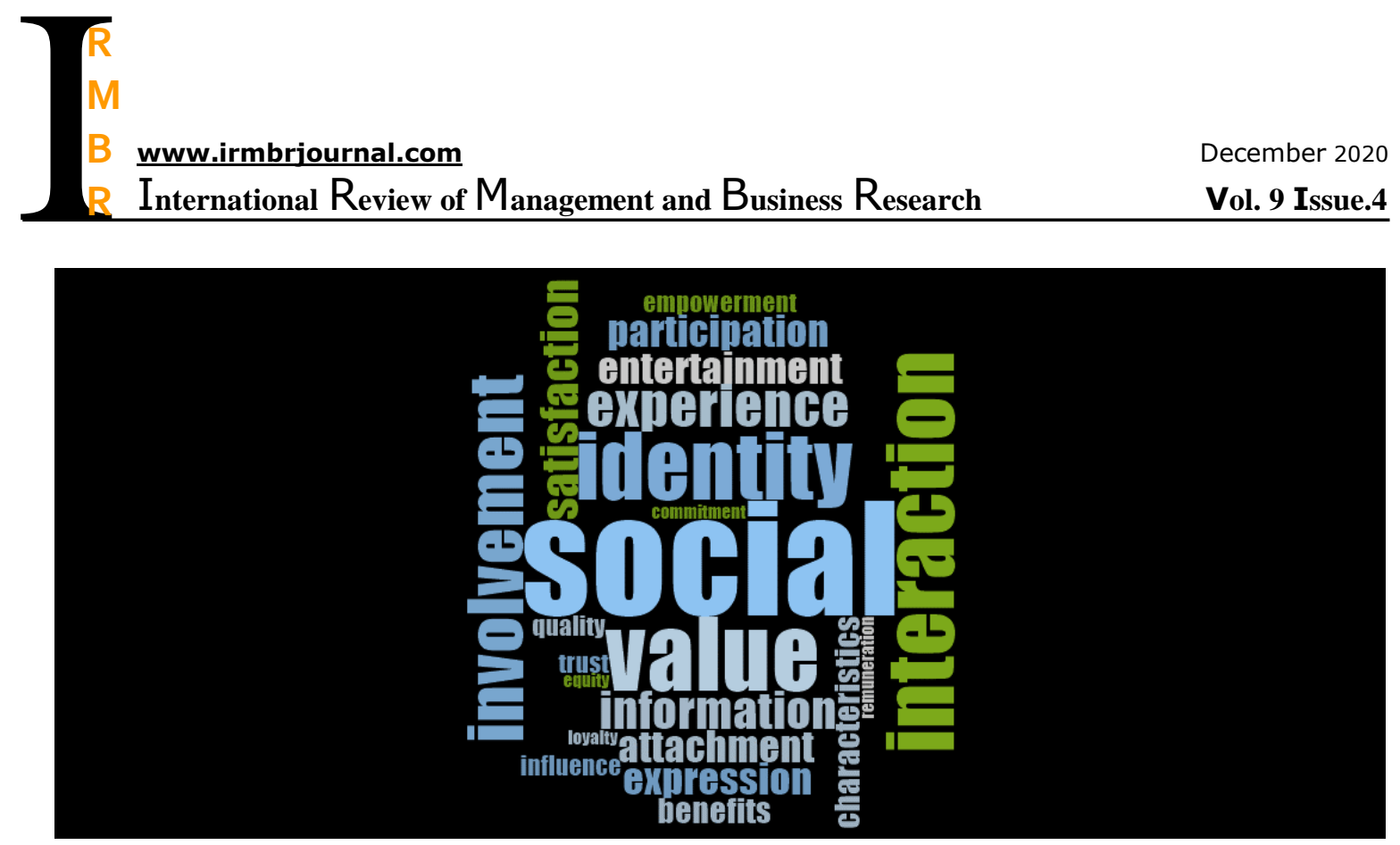

\section{Analysis and Discussion}

it is evident that the interest and importance of consumer engagement is growing with the passage of time. A year wise list of research papers included in this research (mentioned in appendix) depicts the fact. it can also be verified as a lot of research on consumer engagement has been published but after filtering based on a specific quality criterion, there is gradual increase on quality research every year on consumer engagement.

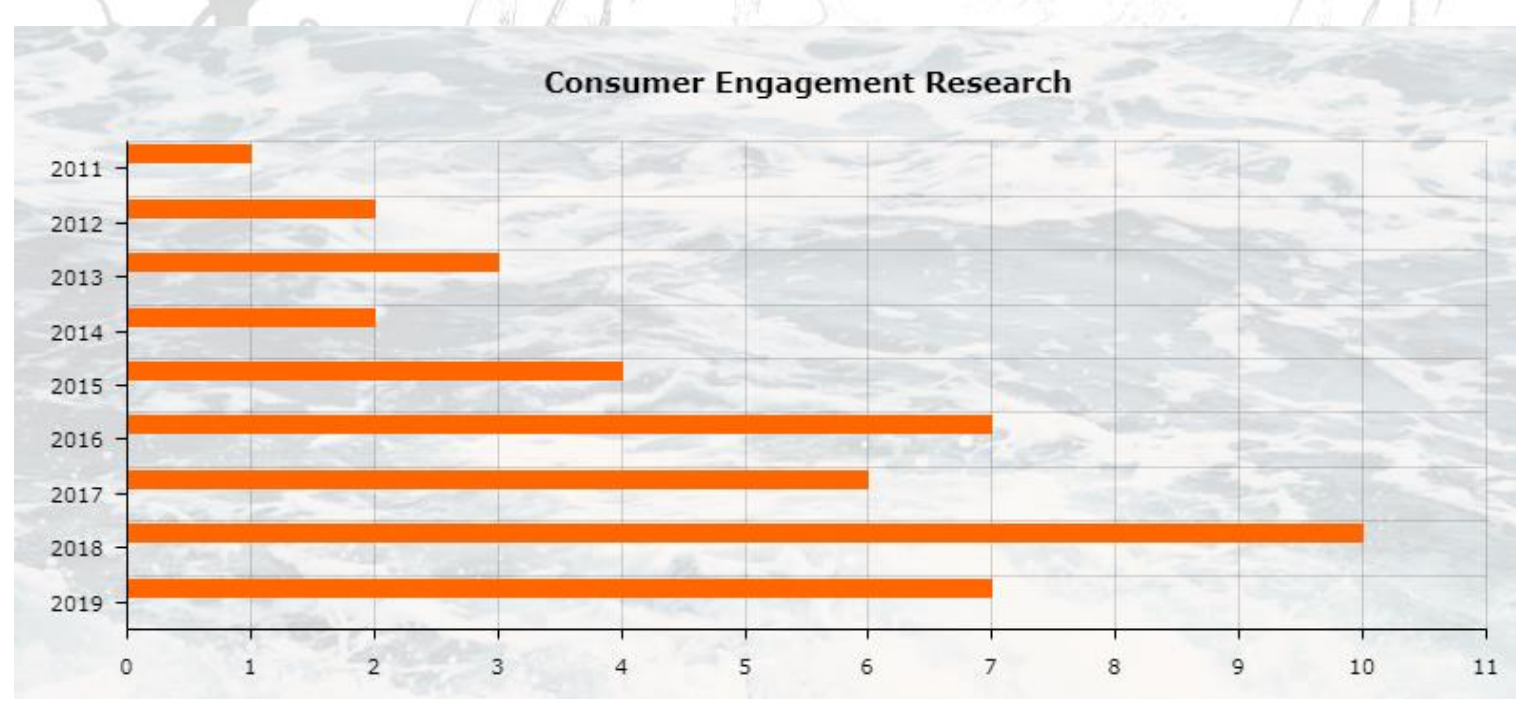

Table 1 illustrate the work of previous researchers on the antecedents of consumer/customer engagement. Although less research has been done, the table depicts that there are versatility and lack of consensus on the antecedents of engagement in marketing literature. The expected reason might be the context and culture-dependent nature of engagement construct. For example, different researchers have explored the social antecedent of consumer engagement differently. They have covered it under different headings like social integration, social tie, social identity, sociability social intercourse, Social value, social influence, etc. A detailed review of previous researchers revealed that although there is a lack of consensus on the specific antecedents, the broader level is homogeneous. This study has arranged antecedents based on the broader level. Table 2 elaborated such broader areas and showed them based on the number of occurrences 
in previous literature. Among the twenty different broader antecedents, this study will discuss the top ten most repetitive antecedents.

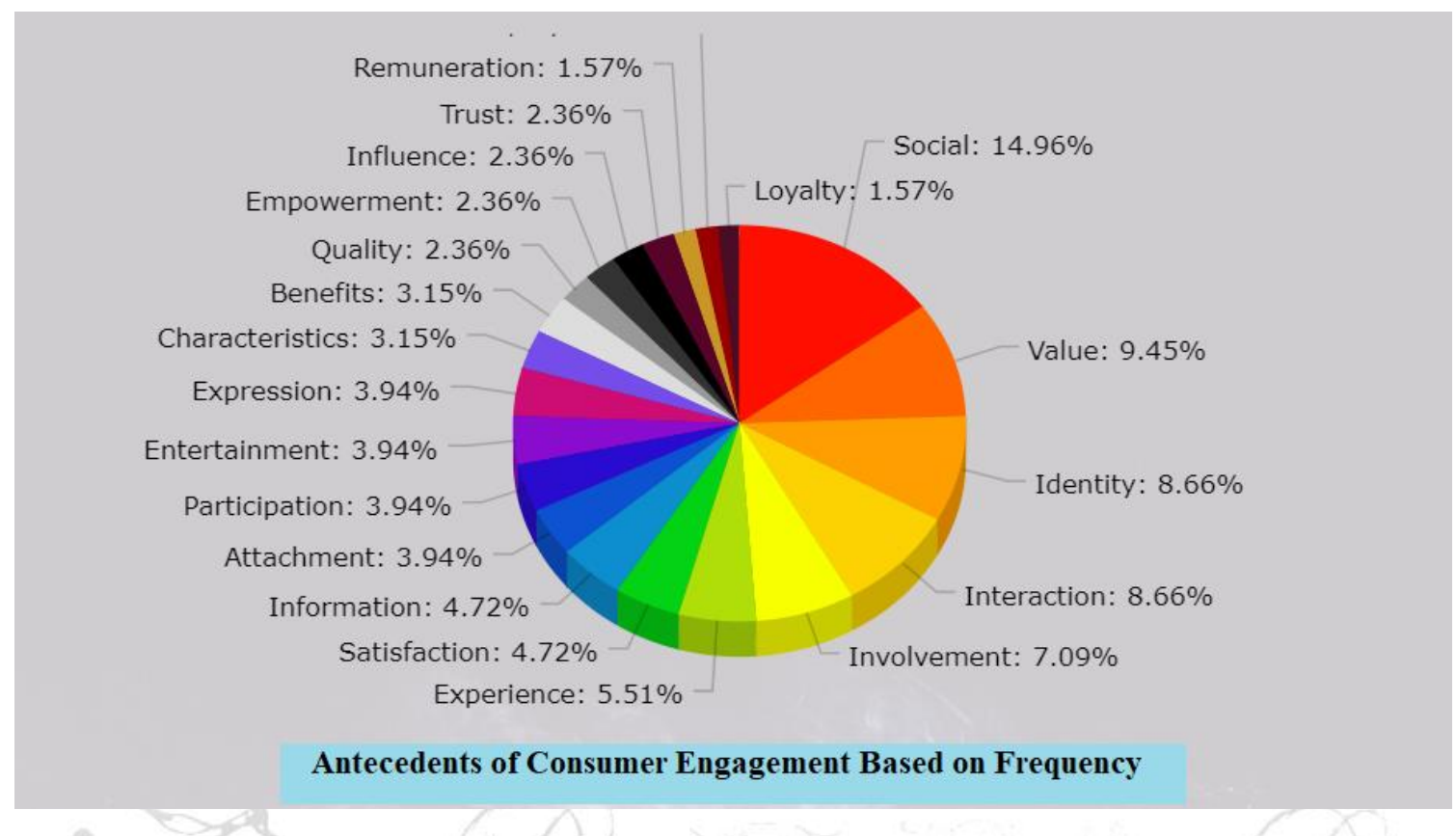

\section{Social Antecedents}

Social antecedents of consumer engagement are not a single term or construct, but a series of subconstructs came under it. Different authors have covered it under different names and aspects. This study has brought under all the antecedents under one heading of social antecedents. Choi (2019) discussed social tie and social identity, Romero (2018) emphasized on the social interaction as an antecedent of consumer engagement, $\mathrm{Li}$ (2013) introduced social intercourse as a new antecedent, Hinson et al. (2019) discussed social interaction ties. Moreover, social integration and social identity discussed by Bejtagi-Maki (2013), para-social interaction by Tsai \& Men (2013), social values by De Vries \& Carlson (2014), social capital, social influence by Jayasingh \$ Venkatesh (2016), social interaction value by Jahn et al. (2012) and social factors like social benefits and social identity were discussed by Chu \& Kim (2011).

Systematic literature reviews of consumer engagement antecedents have revealed that social antecedent broadly is one of the most important antecedents of consumer engagement. Environment, culture, and society as a whole act as the major precursor of any social antecedent. It is one of the antecedents which are free from all context. No matter what the context is, social antecedents always incorporate their role in consumer engagement.

\section{Value Antecedents}

Value antecedent, covered by many authors like community value by Chan et al. (2014), Value-congruity by J. Kumar \& Nayak (2019), Value-based Affinity by Graffigna \& Gambetti (2015), hedonic value and social value by Klepek (2018), again social value by De Vries \& Carlson (2014) and functional value, hedonic value, self-concept value, social interaction value, by Jahn et al. (2012).

According to Woodruff (1997), term value has been viewed in different contexts and meanings, but dominantly, it covers the value form the organization's perspective and value form the customer's 
perspective. The concept of customer value concept deals with the nature, dimensions and structure of value from the perspective of customer (V. Kumar \& Reinartz, 2016; Sayil, Akyol, \& Golbasi Simsek, 2019; Venkatesan, Petersen, \& Guissoni, 2018; Yrjölä, Kuusela, Närvänen, Rintamäki, \& Saarijärvi, 2019). Organizations' perspective covers the monetary value of high-value customers (value of the customers, recently known as customer lifetime value CLV) whereas customer's perspective of value (customer perceived value or customer received value) deals with what customer want and believe that they get from using a specific product or service from a seller (Smith \& Colgate, 2007). Both perspectives are widely used in consumer behavior research as well as in strategy and management literature.

The customer value creation is recognized as the core concept of marketing (Woodruff, 1997) and the central basis for all marketing activity (Yrjölä et al., 2019). It is acknowledged as the purpose of organizations (V. Kumar \& Reinartz, 2016), an essential key to achievement via differential positioning for organizations (Smith \& Colgate, 2007) and an antecedent and active influencer to customer satisfaction and loyalty (Sayil et al., 2019).

According to Zeithaml (1988), "consumer's overall assessment of the value of the utility of a product founded on perception of what is given and what is received." Woodruff (1997) defined customer value as "a customer's perceived preference for, and evaluation of, those product attributes performances, and consequences arising from use that facilitates (or blocks) achieving the customer's goals and purposes in use situations." Holbrook (2005) defines customer value as an "interactive, relativistic preference and experience." Yrjölä et al. (2019) defined customer value as "an economical, functional, emotional, and symbolic outcome of the evaluation of customer-experienced benefits and sacrifices throughout the prepurchase, purchase and post-purchase stages."

All the definitions may express different meanings, but there are certain aspects and characteristics of customer values that these definitions address collectively. Customer value is perceived individually by each customer; it is contextual and conditional based on the individual, product, and situation, it is relative (alternatives) and dynamic (changing over time) (Ulaga, 2003). Smith \& Colgate (2007) recognize four types of value customers draw from a firm. These values include functional/instrumental value, experiential/hedonic value, symbolic/expressive value and cost/sacrifice value. From the perspective of firms, V. Kumar et al. (2010) identify the four components of customer engagement values. These components are customer lifetime value, customer referral value, customer influencer value, and customer knowledge value.

Sheth, Newman, \& Gross (1991) developed a theory that explains the phenomenon of consumption values. It explains why consumer prefer one brand on another brand, why consumer decides to choose one product on another product, why they decide to buy or not to buy a specific product. This theory explains that customers draw five types of value from consumption. These consumption values are conditional value, social value, emotional value, functional value, and epistemic value.

\section{Identity/identification}

Identity/identification is one of the most important antecedents of consumer engagement. According to the Merriam-Webster dictionary, "identity is the distinguishing character or personality of an individual." Studies in the current literature review have discussed identification antecedents under different angles. Hinson et al. (2019) discussed identity antecedent as the Identity-based attachment where brand identification act as an antecedent of consumer engagement. Choi (2019) discussed about social identity, Romero (2017) discussed about identity, again Romero (2018) discussed it under company identification, Dhamore \& Balaji (2016) discussed about identification, Bejtagi-Maki (2013) discussed about social identity, Vale and Fernandes (2017) discussed about personal identification, Tsai \& Men (2013) discussed it as community identification, Buechel \& Berger (2015) discussed it as self-expression and identity representation. Whereas Weitzl \& Einwiller (2018) covered it in two ways, first under Brand-based 
antecedent factors of consumer engagement which include brand identification and secondly under social factors which covers social identification.

Kucharska (2019) explained the brand identification of consumers as the "perceived feeling of oneness with a brand and is supported by social interactions." Also, brand identification is the sharing of an individual's definitional attributes with a specific brand by a consumer (Yeh, Wang, \& Yieh, 2016). As far as social identification is concerned, Tajfel (1981) defined it as "that part of an individual's self-concept which derives from his knowledge of his membership in a social group/groups together with the value and emotional significance attached to that membership." On the other hand, personal identity denotes how people as an individual see themselves, and it addresses several individual attributes like sociability, competence and talent (Lantz \& Loeb, 1998).

\section{Interaction}

Ko, Roberts, \& Cho (2006) defined Interaction or interactivity as the degree to which individuals engage in a communication activity by enthusiastically interacting through mediated messages and other people. Interactivity is an essential antecedent of consumer engagement. Various authors have widely discussed it under different angles. For example, Schultz (2017) and Choi (2019) discussed the construct interactivity as an antecedent of consumer engagement. France et al. (2016) covered it under brand interactivity and considered it as one of the firm-led drivers of consumer engagement. Dhamore \& Balaji (2016) discussed it as interaction. Jahn et al. (2012) discussed it as a brand interaction value. Brand interactivity is the interaction of the individual with the brand by mean of a platform. Jahn et al. (2012) discussed that the interaction between user and brand and the user with other users could be of value for consumers.

Authors like Hinson et al. (2019), Vale and Fernandes (2017), Tsai \& Men (2013), and Jahn et al. (2012) discussed it as social interaction throughout the literature. Social interaction is the process through which individuals act and react concerning one another (Mele, 2017). Interaction, whether it is brand interaction or social interaction, both are of equal importance and have a higher ranking in top antecedents of consumer engagement.

\section{Involvement}

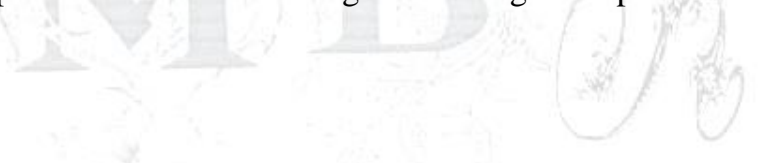

Involvement is a motivational state of mind of a person concerning an object or activity, and it reveals itself as the level of interest in that object or activity (Banwari Mittal, 1983; Banwari Mittal \& Lee, 1989). Involvement can be of different types like the product, brand, or purchase decision involvement. Banwari Mittal \& Lee (1989) Distinguished product involvement with brand involvement as; Product Involvement is the consumers' interest in a specific product category. Brand Involvement is the consumers' interest in making a brand selection.

Purchase-decision involvement can be defined as the degree to which consumers care about what they buy accordingly and the degree to which they are motivated to make it to the best choice." (Banwari Mittal, 1989). Banwari Mittal \& Lee (1989) explained that product sign value, product hedonic value, product risk value, and product utility are the proposed antecedents. Moreover, the consequences can be the extensiveness of the decision-making process and interest in advertising. Some other consequence can be brand-commitments, regularity of product-usage, shopping amusement, and social observations of brand usage.

Moreover, customer involvement is an essential antecedent of customer engagement and required preceding to the expression of individual customer-relevant engagement level (Brodie et al., 2011; Vivek, Beatty, Dalela, \& Morgan, 2014). Customer involvement is a psychological construct, while customer engagement is not merely a psychological construct but emotional behaviors too. Moreover, customer involvement does not cover customer behavior at all although involvement can be a precursor of customer 
engagement in the context of behavioral conceptualization and can act as an antecedent of customer engagement (Vivek, Beatty, \& Morgan, 2012).

Customer involvement deals with the information-seeking phenomenon before the purchase to avoid any adverse consequences later for the individual customer (Delgado-Ballester \& Luis Munuera-Alemán, 2001), all this is done before customer make a purchase, while engagement involves the purchase and other indirect actions (Pansari \& Kumar, 2017).

\section{Information}

Information is defined as "something which, when perceived effect and transform the recipient's state of knowledge"(Ingwersen, 1992). The very definition of information reveals the importance of it as an antecedent of consumer engagement. Many authors have discussed and emphasized the information as a very cogent and highly ranked antecedent of consumer engagement. Li (2013) and Vale \& Fernandes (2017) discussed it as information, Reitz (2012) discussed it as perceived information quality, Buechel \& Berger (2015) discussed it under Information retrieval and dissemination and Chu \& Kim (2011) covered it under information influence construct. Awareness and reach to information play a vital role in getting engagement of consumers with the brand. Perceived information quality, for example, plays a vital role in getting consumer engaged because information quality matters a lot for end users and have the potential to overcome negativity and change it into positivity regarding a brand or vice versa.

\section{Satisfaction}

In the current literature review, six authors have discussed satisfaction as the critical antecedent of consumer engagement. Satisfaction is a highly researched construct throughout the business literature. It has been discussed in a different context, for example, life satisfaction, job satisfaction, work satisfaction, and employee satisfaction. In consumer engagement literature, satisfaction has proved itself as a contextfree antecedent of consumer engagement. Consumer satisfaction can be defined as the feeling of fulfillment a consumer received after using a particular service or product. A satisfied customer will be highly engaged with a product or brand. Explained in their theory of engagement and argued that if a customer is satisfied and emotionally connected with a product or brand, then both partners (consumer and brand) are engaged (Pansari \& Kumar, 2017)

\section{Experience}

Customer experience is broad and encompasses the physical responses, emotional, cognitive, social and affective responses of retailer (Verhoef et al., 2009). According to Brodie et al. (2011), engagement happens due to collaborative and mutually creative customer experiences with a focal agent. According to this definition, engagement can arise due to various experiences with the product or services. Moreover, engagement is not only produced due to the actions of firms but can also be produced due to other valued experiences (Calder, Isaac, \& Malthouse, 2016).

Homburg, Jozić, \& Kuehnl (2017) explained that customer experience is the progression of a person's relational, affective, relational, sensorial, cognitive, and behavioral responses to a firm or brand by living through an excursion of touchpoints along with the pre-purchase, purchase, and post-purchase conditions. According to Venkatesan et al. (2018), much research has been done about the experiences from prepurchase to post-purchase that can generate repeated transaction and maximize it, but the role of experiences in creating values for customers so that they can advocate a brand or provide valuable feedback that can lead to developing a newer or better product is unknown.

This Experiential view perspective is phenomenological and regards consumption as a subjective state of consciousness accompanied by a diversity of hedonic responses, symbolic meaning, and aesthetic criteria. 
The new perspective can answer the question like the role of aesthetic products, product associated fancies, the multisensory facet of product pleasure, imagery, and sensation arising from consumptions (Holbrook \& Hirschman, 1982).

\section{Participation}

Dabholkar (2015) defined customer participation as the degree to which customer is immersed in service fabrication and delivery by contributing efforts, expertise, information, and additional sources." It has three mandatory types, voluntarily and replicable customer participation (Dong \& Sivakumar, 2017). Potential antecedents and consequences of customer participation depend upon the context and situation. Potential antecedents may include self-efficacy, role clarity, and purchase importance in mandatory participation context (S. C. Chen, Raab, \& Tanford, 2015).

Customers' participation in the brand community's context includes antecedents like identification with the community, degree of influence, and satisfaction with the community. Moreover, recommending behavior, community sponsor's image of brand, and intentions of customers to maintain community memberships might be the potential consequences of customer's participation in communities of the brands (Woisetschläger, Hartleb, \& Blut, 2008). In another context, identify five specific and three broad antecedents of consumer participation were identified. These antecedents include information, entertainment, social integration, self-discovery, and social enhancement. The broad antecedents include moral responsibility, the consciousness of kindness, and shared rituals and traditions. Moreover, sustainable brand loyalty and brand recommendation intention were identified as the consequences of consumer participation Madupu \& Cooley (2010).

Customer participation takes place during service transaction while customer engagement goes beyond the service transaction and include an indirect contribution of customers. Moreover, customer engagement is voluntary, but customer participation may be mandatory or replaceable participation, too (Vivek et al., 2012). Customer participation is an essential antecedent of customer engagement and required preceding to the expression of individual customer-relevant engagement level (Brodie et al., 2011; Vivek et al., 2014)

\section{Attachment}

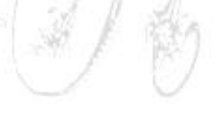

Dwayne Ball \& Tasaki (1992) defined the attachment as the degree to which an object is owned, likely to be owned, or earlier owned by the individual, which is utilized by the specific individual to sustain the selfconcept of himself or herself."

Attachment is a broader concept and been employed in the management context too. In management, customer attachment expresses the cognitive state of association or identification with an organization (Buttle, 1998). Attachment is all about possession and maintaining self-concept in the process. There are two sides of the self in the domain of attachment; the private self and the public self. Grisaffe \& Nguyen (2011) explored the antecedents of brand attachment, which are user-driven benefits, traditional customer outcomes, superior marketing characteristics, inter-organizational influence, and sentimental/emotional memories. The attachment measurement scale developed by Dwayne Ball \& Tasaki (1992) proposes that possession is vital in supporting and preserving consumers' sense of self-worth and identity. Attachment is reliable and an active construct and associated with possession or ownership of products or objects, so it differs from engagement in this way, but in some situations, it could lead to consumer engagement (Vivek et al., 2012).

\section{Conclusion}

The systematic literature review was planned to investigate the antecedents of consumer engagement and to determine the generalizable antecedents of consumer engagement. For this purpose, strict inclusion and 
exclusion criteria implemented. Among hundreds of articles, a total 42 articles were selected, which fulfilled the criteria. Strict criteria were necessary to improve the quality of work. The study compiled all the antecedents in a table and initiated the endeavor to conclude some highly ranked and high-frequency antecedents. A total of 22 antecedents were portrayed among which, the study has discussed the topmost highly relevant yet most essential antecedents of consumer engagement. The research generalized the antecedes under broader terms. These top antecedent terms are social, Value, Identity, Interaction, Involvement, Experience, Satisfaction, Information, Attachment, and participation were most essential and were ranked according to frequency.

\section{Implications for Research}

Managers are more inclined to know the new types of engagement through which they can engage customers and draw value from them. For example, encouraging the customer to be part of gifting behavior actively engage the customers with the firm and ultimately leads to more profit for the firm (V. Kumar \& Reinartz, 2016). Managers will be able to know which antecedent has the most crucial impact on engaging consumers. By focusing on the most promising one will, consequently, enhance their profit.

This research will educate the managers to incorporate and manipulate different antecedents wisely and strategically to achieve an engaged customer. An engaged customer is way more loyal than any other customer. An engaged customer will value more than any other customer. An engaged customer will refer other customers to be the part of the firm or brand to which he is engaged. The research depicts that a customer with some referrer worth twice than the customer acquired through traditional means. The Gallup research depicts that an engaged customer represents a $23 \%$ premium in the shape of profitability, relationship growth, wallet share, and revenue over an average customer across the hospitality industry, retail, and consumer electronics (Venkatesan et al., 2018).

This research will assist the managers in refining the engagement strategies designed to increase customer value creation. Customer value dimensions (economic, functional, emotional, and symbolic) can be incorporated to create an actionable and concrete procedure through which customer orientation can be employed in the executive level decision making process (Yrjölä et al., 2019).

Maslowska, Malthouse, \& Collinger (2016), in their research on customer engagement, highlighted the need for the creation of a general framework that could be applied and tested into various environments and contexts. The current systematic literature review has established foundations for the general framework by introducing some agreed antecedents applicable to almost any context.

In today's competitive business world, businesses are struggling to survive. Being creative about enhancing and creating customer value and engagement might empower the marketers to be more effective, profitable and explore more unexplored opportunities. Managers will be able to capture the aspects which contribute more engagement and value for the consumers. By knowing that value, the manager can enhance, manipulate it, and optimally implement it in other relevant products.

This study will help the managers to find which antecedent causes the least value for the consumers. By manipulating, that antecedent, managers can enhance engagement or can use it to cost cut by totally eradicating that profit hole. For companies based on the sharing economy model, the values perceived by customers can be the starting point for effective strategy planning (Nguyen, Rintamäki, \& Saarijärvi, 2018).

\section{Limitation and Future Work}

Like any research, the current systematic review also has some limitations. Strict inclusion and exclusion criteria bound us to exclude some highly relevant articles from a systematic literature review. Although, the current systematic literature review discussed and concluded some antecedents which are frequently 
researched and less affected by a specific context, yet many antecedents are particular to the context and could not be included in the generalized findings.

\section{Future Research Directions}

Following areas are yet unexplored and there is scope of future research.

1. Future research is needed on consumer engagement in the different contexts and cultural settings as engagement is a construct highly dependent on context (Hollebeek, 2011). Research on different contexts like consumer engagement in sharing economy is much demanded (Breidbach \& Brodie, 2017).

2. The current study addresses the systematic literature review on the antecedents of consumer engagement, but a systematic literature review addressing the consequences of consumer engagement will be a noteworthy enhancement to the body of knowledge.

3. Consumer engagement in the context of religion's impact on consumer behaviour is the area need to be exploreed as it is unidentified area in enosumer engagement research so far.

4. New construct like consumer inspiration need to be evaluated as an antecedents of conumer engagement.

5. Impact of personality types on cosumer engagement in various context will be an interesting area to explore.

6. Engagement is a versatile construct and moves hand in hand with the latest technological development. Current technologies have acquired greater consumer engagement than traditional means. There is a need for future research to explore consumer engagement in the context of modern technologies like artificial intelligence, augmented reality and virtual reality, hologram, big data, intelligent apps, blockchain, internet of things, etc. Engagement is a never-ending process, and it evolves all the time.

\section{References}
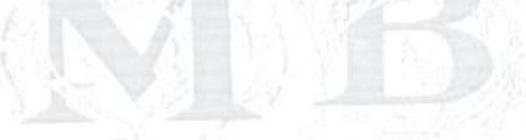

Abdul-Ghani, E., Hyde, K. F., \& Marshall, R. (2018). Conceptualising engagement in a consumer-toconsumer context. Australasian Marketing Journal (AMJ).

Abdullah, \& Siraj, S. (2018). Antecedents and consequences of the process of customer engagement through social media: an integrated conceptual framework. International Journal of Electronic Business, 14(1), 1-27.

Ahn, J., \& Back, K.-J. (2018). Antecedents and consequences of customer brand engagement in integrated resorts. International Journal of Hospitality Management, 75, 144-152.

Algharabat, R., Rana, N. P., Alalwan, A. A., Baabdullah, A., \& Gupta, A. (2019). Investigating the antecedents of customer brand engagement and consumer-based brand equity in social media. Journal of Retailing and Consumer Services.

Alibage, A., \& Jetter, A. (2017). Drivers of Consumers' Emotional Engagement with Everyday Products: An Intensive Review of the Literature and an Attempt to Conceptualize the Consumer-Product Interactions Within the Emotional Design Process.

Alversia, Y., Michaelidou, N., \& Moraes, C. (2016). Online consumer engagement behaviour: the consumer-based antecedents. In Looking Forward, Looking Back: Drawing on the Past to Shape the Future of Marketing (pp. 849-852): Springer.

Axelson, R. D., \& Flick, A. (2010). Defining student engagement. Change: The magazine of higher learning, 43(1), 38-43.

Bejtagi-Maki, M. (2013). Key drivers for customer engagement on Facebook brand fan pages in Bosnia and Herzegovina. Paper presented at the International Conference on Economic and Social Studies.

Bilro, R. G., \& Loureiro, S. M. C. J. S. J. o. M.-E. (2020). A consumer engagement systematic review: synthesis and research agenda. 
Bowden, J. L. (2009). The process of customer engagement: A conceptual framework. Journal of marketing theory and practice, 17(1), 63-74.

Breidbach, C. F., \& Brodie, R. J. (2017). Engagement platforms in the sharing economy: conceptual foundations and research directions. Journal of Service Theory and Practice, 27(4), 761-777.

Brodie, R. J., Hollebeek, L. D., Jurić, B., \& Ilić, A. (2011). Customer engagement: conceptual domain, fundamental propositions, and implications for research. Journal of service research, 14(3), 252-271.

Brodie, R. J., Ilic, A., Juric, B., \& Hollebeek, L. (2013). Consumer engagement in a virtual brand community: An exploratory analysis. Journal of business research, 66(1), 105-114.

Buechel, E. C., \& Berger, J. (2015). Motivations for consumer engagement with social media. In Consumer Psychology in a social media world (pp. 31-50): Routledge.

Buttle, F. (1998). Customer attachment: a conceptual model of customer-organisation linkage.

Calder, B. J., Isaac, M. S., \& Malthouse, E. C. (2016). How to capture consumer experiences: A contextspecific approach to measuring engagement: Predicting consumer behavior across qualitatively different experiences. Journal of Advertising Research, 56(1), 39-52.

Calder, B. J., Malthouse, E. C., \& Schaedel, U. (2009). An experimental study of the relationship between online engagement and advertising effectiveness. Journal of interactive marketing, 23(4), 321-331.

Cambra-Fierro, J., \& Melero-Polo, I. (2017). Complaint-handling as antecedent of customer engagement: do consumer characteristics matter? Marketing Intelligence \& Planning, 35(2), 277-295.

Chan, T. K., Zheng, X., Cheung, C. M., Lee, M. K., \& Lee, Z. W. (2014). Antecedents and consequences of customer engagement in online brand communities. Journal of Marketing Analytics, 2(2), 81-97.

Chen, J.-S., Weng, H.-H., \& Huang, C.-L. (2018). A multilevel analysis of customer engagement, its antecedents, and the effects on service innovation. Total Quality Management \& Business Excellence, 29(3-4), 410-428.

Chen, S. C., Raab, C., \& Tanford, S. (2015). Antecedents of mandatory customer participation in service encounters: An empirical study. International Journal of Hospitality Management, 46, 65-75.

Chiang, C.-T., Wei, C.-F., Parker, K. R., \& Davey, B. (2017). Exploring the drivers of customer engagement behaviours in social network brand communities: towards a customer-learning model. Journal of marketing management, 33(17-18), 1443-1464.

Choi, Y. (2019). The Study of Antecedents of Consumer Engagement and Purchase Intention in Social Commerce. International Journal of Cyber Behavior, Psychology and Learning (IJCBPL), 9(2), 51-63.

Chu, S.-C., \& Kim, Y. (2011). Determinants of consumer engagement in electronic word-of-mouth (eWOM) in social networking sites. International journal of Advertising, 30(1), 47-75.

Dabholkar, P. A. (2015). How to improve perceived service quality by increasing customer participation. Paper presented at the Proceedings of the 1990 academy of marketing science (AMS) annual conference.

De Vries, N. J., \& Carlson, J. (2014). Examining the drivers and brand performance implications of customer engagement with brands in the social media environment. Journal of Brand Management, 21(6), 495-515.

Delgado-Ballester, E., \& Luis Munuera-Alemán, J. (2001). Brand trust in the context of consumer loyalty. European Journal of Marketing, 35(11/12), 1238-1258.

Dessart, L., Veloutsou, C., \& Morgan-Thomas, A. (2016). Capturing consumer engagement: duality, dimensionality and measurement. Journal of marketing management, 32(5-6), 399-426.

Dhamore, V. G., \& Balaji, B. (2016). Customer engagement in e-tailing: antecedents, outcomes and implications.

Dong, B., \& Sivakumar, K. (2017). Customer participation in services: domain, scope, and boundaries. Journal of the Academy of Marketing Science, 45(6), 944-965.

Dwayne Ball, A., \& Tasaki, L. H. (1992). The role and measurement of attachment in consumer behavior. Journal of Consumer Psychology, 1(2), 155-172.

Dwivedi, A., Wilkie, D., Johnson, L., \& Weerawardena, J. (2016). Establishing measures and drivers of consumer brand engagement behaviours. Journal of Brand Management, 23(5), 41-69.

Fehrer, J. A., Woratschek, H., Germelmann, C. C., \& Brodie, R. J. (2018). Dynamics and drivers of customer engagement: within the dyad and beyond. Journal of Service Management, 29(3), 443-467. 
Fink, A. (2019). Conducting research literature reviews: From the internet to paper: Sage publications.

France, C., Merrilees, B., \& Miller, D. (2016). An integrated model of customer-brand engagement: Drivers and consequences. Journal of Brand Management, 23(2), 119-136.

Gavilanes, J. M., Flatten, T. C., \& Brettel, M. (2018). Content strategies for digital consumer engagement in social networks: Why advertising is an antecedent of engagement. Journal of advertising, 47(1), 423.

Glavee-Geo, R., Shaikh, A. A., Karjaluoto, H., \& Hinson, R. E. (2019). Drivers and outcomes of consumer engagement. International journal of bank marketing.

Graffigna, G., \& Gambetti, R. C. (2015). Grounding consumer-brand engagement: A field-driven conceptualisation. International Journal of Market Research, 57(4), 605-630.

Grisaffe, D. B., \& Nguyen, H. P. (2011). Antecedents of emotional attachment to brands. Journal of business research, 64(10), 1052-1059.

Higgins, E. T., \& Scholer, A. A. (2009). Engaging the consumer: The science and art of the value creation process. Journal of Consumer Psychology, 19(2), 100-114.

Hinson, R., Boateng, H., Renner, A., \& Kosiba, J. P. B. (2019). Antecedents and consequences of customer engagement on Facebook: An attachment theory perspective. Journal of Research in Interactive Marketing.

Holbrook, M. B. (2005). Customer value and autoethnography: subjective personal introspection and the meanings of a photograph collection. Journal of business research, 58(1), 45-61.

Holbrook, M. B., \& Hirschman, E. C. (1982). The experiential aspects of consumption: Consumer fantasies, feelings, and fun. Journal of Consumer Research, 9(2), 132-140.

Hollebeek, L. D. (2011). Exploring customer brand engagement: definition and themes. Journal of strategic Marketing, 19(7), 555-573.

Hollebeek, L. D., Srivastava, R. K., \& Chen, T. (2019). SD logic-informed customer engagement: integrative framework, revised fundamental propositions, and application to CRM. Journal of the Academy of Marketing Science, 47(1), 161-185.

Homburg, C., Jozić, D., \& Kuehnl, C. (2017). Customer experience management: toward implementing an evolving marketing concept. Journal of the Academy of Marketing Science, 45(3), 377-401.

Ingwersen, P. (1992). Information retrieval interaction (Vol. 246): Taylor Graham London.

Jaakkola, E., \& Alexander, M. (2014). The role of customer engagement behavior in value co-creation: a service system perspective. Journal of service research, 17(3), 247-261.

Jahn, B., Kunz, W., \& Meyer, A. (2012). The role of social media for luxury brands-Motives for consumer engagement and opportunities for business. In Identitätsbasierte Luxusmarkenführung (pp. 221-236): Springer.

Jayasingh, S., \& Venkatesh, R. (2016). Determinants of Customer Brand Engagement in Social Media Sites: A Conceptual Framework. International Business Management, 10(15), 2802-2807.

Kitchenham, B., \& Charters, S. (2007). Guidelines for performing systematic literature reviews in software engineering.

Klepek, M. (2018). Determinants of customer engagement on Facebook brand pages. Scientific papers of the University of Pardubice. Series D, Faculty of Economics and Administration. 44/2018.

Ko, H., Roberts, M. S., \& Cho, C.-H. (2006). Cross-cultural differences in motivations and perceived interactivity: a comparative study of American and Korean internet users. Journal of Current Issues \& Research in Advertising, 28(2), 93-104.

Kucharska, W. (2019). Online brand communities' contribution to digital business models. Journal of Research in Interactive Marketing.

Kumar, J., \& Nayak, J. K. (2019). Consumer psychological motivations to customer brand engagement: a case of brand community. Journal of Consumer Marketing, 36(1), 168-177.

Kumar, V., Aksoy, L., Donkers, B., Venkatesan, R., Wiesel, T., \& Tillmanns, S. (2010). Undervalued or overvalued customers: capturing total customer engagement value. Journal of service research, 13(3), 297-310.

Kumar, V., \& Reinartz, W. (2016). Creating enduring customer value. Journal of marketing, 80(6), 36-68. 
Kunz, W., Aksoy, L., Bart, Y., Heinonen, K., Kabadayi, S., Ordenes, F. V., . . Theodoulidis, B. (2017). Customer engagement in a big data world. Journal of Services Marketing, 31(2), 161-171.

Lantz, G., \& Loeb, S. (1998). An examination of the community identity and purchase preferences using the social identity approach. ACR North American Advances.

Leckie, C., Nyadzayo, M. W., \& Johnson, L. W. (2016). Antecedents of consumer brand engagement and brand loyalty. Journal of marketing management, 32(5-6), 558-578.

Levy, Y., \& Ellis, T. J. (2006). A systems approach to conduct an effective literature review in support of information systems research. Informing Science, 9.

Li, D. H. (2013). Research on motivations of consumer engagement in online brand community. Paper presented at the Applied Mechanics and Materials.

Madupu, V., \& Cooley, D. O. (2010). Antecedents and consequences of online brand community participation: a conceptual framework. Journal of Internet Commerce, 9(2), 127-147.

Maslowska, E., Malthouse, E. C., \& Collinger, T. (2016). The customer engagement ecosystem. Journal of marketing management, 32(5-6), 469-501.

Mele, V. (2017). Social interaction. The Wiley-Blackwell Encyclopedia of Social Theory, 1-4.

Mittal, B. (1983). Understanding the Bases and Effects of Involvement in the Consumer Choice Process.

Mittal, B. (1989). Measuring purchase-decision involvement. Psychology \& Marketing, 6(2), 147-162.

Mittal, B., \& Lee, M.-S. (1989). A causal model of consumer involvement. Journal of economic psychology, 10(3), 363-389.

Nguyen, H. N., Rintamäki, T., \& Saarijärvi, H. (2018). Customer value in the sharing economy platform: the Airbnb Case. In Collaborative Value Co-creation in the Platform Economy (pp. 225-246): Springer.

Pansari, A., \& Kumar, V. (2017). Customer engagement: the construct, antecedents, and consequences. Journal of the Academy of Marketing Science, 45(3), 294-311.

Patterson, P., Yu, T., \& De Ruyter, K. (2006). Understanding customer engagement in services. Paper presented at the Advancing theory, maintaining relevance, proceedings of ANZMAC 2006 conference, Brisbane.

Rather, R. A., Hollebeek, L. D., \& Islam, J. U. (2019). Tourism-based customer engagement: the construct, antecedents, and consequences. The Service Industries Journal, 39(7-8), 519-540.

Reitz, A. R. (2012). Online consumer engagement: Understanding the antecedents and outcomes. Colorado State University. Libraries,

Romero, J. (2017). Customer engagement behaviors in hospitality: Customer-based antecedents. Journal of Hospitality Marketing \& Management, 26(6), 565-584.

Romero, J. (2018). Exploring customer engagement in tourism: Construct proposal and antecedents. Journal of Vacation Marketing, 24(4), 293-306.

Sayil, E. M., Akyol, A., \& Golbasi Simsek, G. (2019). An integrative approach to relationship marketing, customer value, and customer outcomes in the retail banking industry: a customer-based perspective from Turkey. The Service Industries Journal, 39(5-6), 420-461.

Schivinski, B., Christodoulides, G., \& Dabrowski, D. (2016). Measuring consumers' engagement with brand-related social-media content: development and validation of a scale that identifies levels of social-media engagement with brands. Journal of Advertising Research, 56(1), 64-80.

Schultz, C. D. (2017). Proposing to your fans: Which brand post characteristics drive consumer engagement activities on social media brand pages? Electronic Commerce Research and Applications, 26, 23-34.

Sheth, J. N., Newman, B. I., \& Gross, B. L. (1991). Why we buy what we buy: A theory of consumption values. Journal of business research, 22(2), 159-170.

Smith, J. B., \& Colgate, M. (2007). Customer value creation: a practical framework. Journal of marketing theory and practice, 15(1), 7-23.

Solem, B. A. A. (2015). The process of customer brand engagement in interactive contexts: Prerequisites, conceptual foundations, antecedents, and outcomes. 
Solem, B. A. A., \& Pedersen, P. E. (2016). The role of customer brand engagement in social media: conceptualisation, measurement, antecedents and outcomes. International Journal of Internet Marketing and Advertising, 10(4), 223-254.

Tajfel, H. (1981). Human groups and social categories: Studies in social psychology: Cup Archive.

Tsai, W.-H. S., \& Men, L. R. (2013). Motivations and antecedents of consumer engagement with brand pages on social networking sites. Journal of Interactive Advertising, 13(2), 76-87.

Ulaga, W. (2003). Capturing value creation in business relationships: A customer perspective. Industrial marketing management, 32(8), 677-693.

Unal, G., Schivinski, B., \& Brzozowska-Woś, M. (2017). Literature review on conceptualisation of online consumer engagement. Handel Wewnętrzny(6 (371)), 353-362.

Vale, L., \& Fernandes, T. (2017). Drivers of Consumer Engagement with Sports Clubs on Facebook. In Marketing at the Confluence between Entertainment and Analytics (pp. 1391-1395): Springer.

Van Doorn, J., Lemon, K. N., Mittal, V., Nass, S., Pick, D., Pirner, P., \& Verhoef, P. C. (2010). Customer engagement behavior: theoretical foundations and research directions. Journal of service research, 13(3), 253-266.

Venkatesan, R., Petersen, J. A., \& Guissoni, L. (2018). Measuring and managing customer engagement value through the customer journey. In Customer Engagement Marketing (pp. 53-74): Springer.

Verhoef, P. C., Lemon, K. N., Parasuraman, A., Roggeveen, A., Tsiros, M., \& Schlesinger, L. A. (2009). Customer experience creation: Determinants, dynamics and management strategies. Journal of retailing, $85(1), 31-41$.

Verhoef, P. C., Reinartz, W. J., \& Krafft, M. (2010). Customer engagement as a new perspective in customer management. Journal of service research, 13(3), 247-252.

Vivek, S. D., Beatty, S. E., Dalela, V., \& Morgan, R. M. (2014). A generalized multidimensional scale for measuring customer engagement. Journal of marketing theory and practice, 22(4), 401-420.

Vivek, S. D., Beatty, S. E., \& Hazod, M. (2018). If you build it right, They will engage: a study of antecedent conditions of customer engagement. In Customer Engagement Marketing (pp. 31-51): Springer.

Vivek, S. D., Beatty, S. E., \& Morgan, R. M. (2012). Customer engagement: Exploring customer relationships beyond purchase. Journal of marketing theory and practice, 20(2), 122-146.

Wang, J., Liao, J., Zheng, S., \& Li, B. (2019). Examining Drivers of Brand Community Engagement: The Moderation of Product, Brand and Consumer Characteristics. Sustainability, 11(17), 4672.

Weitzl, W., \& Einwiller, S. (2018). Consumer engagement in the digital era its nature, drivers and outcomes. The handbook of communication engagement, 453.

Woisetschläger, D. M., Hartleb, V., \& Blut, M. (2008). How to make brand communities work: Antecedents and consequences of consumer participation. Journal of Relationship Marketing, 7(3), 237-256.

Woodruff, R. B. (1997). Customer value: the next source for competitive advantage. Journal of the Academy of Marketing Science, 25(2), 139.

Yeh, C.-H., Wang, Y.-S., \& Yieh, K. (2016). Predicting smartphone brand loyalty: Consumer value and consumer-brand identification perspectives. International Journal of Information Management, 36(3), 245-257.

Yrjölä, M., Kuusela, H., Närvänen, E., Rintamäki, T., \& Saarijärvi, H. (2019). Leading Change: A Customer Value Framework. Leading Change in a Complex World: Transdisciplinary Perspectives.

Zeithaml, V. A. (1988). Consumer perceptions of price, quality, and value: a means-end model and synthesis of evidence. Journal of marketing, 52(3), 2-22.

Zhang, T., Kandampully, J., \& Bilgihan, A. (2015). Motivations for customer engagement in online coinnovation communities (OCCs) a conceptual framework. Journal of Hospitality and Tourism Technology, 6(3), 311-328. 